\title{
Strategi Bimbingan dan Konseling Karier Bermutu pada Sekolah Menengah Kejuruan Syuhada Banjarmasin
}

\author{
Jarkawi Jarkawi, Akhmad Rizkhi Ridhani, Didi Susanto \\ Prodi Bimbingan dan Konseling, Fakultas Keguruan Ilmu Pendidikan, Universitas Islam Kalimantan \\ Muhammad Arsyad Al-Banjary, Jl. Adhiyaksa No. 2, Banjarmasin, Kalimantan Selatan, Indonesia 70123 \\ E-mail: rizkhi.ridhani@gmail.com
}

Artikel diterima: 13 Mei 2017; direvisi 12 September 2017; disetujui 16 September 2017

\begin{abstract}
In order to have a clear career direction and career goals, vocational high school students have to think rationally. They need a strategy to realize the desired career dream. This study focuses on how the implementation of career guidance and counseling as well as analysis of Strength Weakness Opportunity Threat (SWOT) on the implementation of career guidance and counseling and strategies undertaken by Sekolah Menengah Kejuruan Syuhada Banjarmasin. The research method used is case study with data mining technique through observation, interview and documentation. The participants were 32 students, two school counselor, one headmaster and one deputy headmaster. The results show that: (1) the implementation of career guidance and counseling in Sekolah Menengah Kejuruan Syuhada Banjarmasin is very supportive for a quality career; (2) SWOT analysis is helpful in conducting quality career guidance and counseling services; (3) school counselor's strategies are effective and efficient. Suggestions aimed at school counselor in order to compile and implement programs based on SWOT analysis, so they can implement a quality career guidance and counseling service
\end{abstract}

Keywords: strategy; guidance and counseling; career; quality

\begin{abstract}
Abstrak: Peserta didik Sekolah Menengah Kejuruan harus berpikir rasional agar memiliki kejelasan arah dan tujuan karier. Perlu suatu strategi bermutu untuk mewujudkan impian karier yang diinginkan. Penelitian ini berfokus pada bagaimana pelaksanaan bimbingan dan konseling karier serta analisis Strength Weakness Opportunity Threat (SWOT) pada pelaksanaan bimbingan dan konseling karier serta strategi yang dilakukan Sekolah Menengah Kejuruan (SMK) Syuhada Banjarmasin. Metode penelitian yang digunakan adalah studi kasus dengan teknik penggalian data melalui observasi dan wawancara serta dokumentasi. Partisipan adalah 32 orang peserta didik, dua orang Guru Bimbingan dan Konseling, satu Kepala Sekolah dan satu Wakil Kepala Sekolah. Hasil menunjukkan bahwa: (1) pelaksanaan bimbingan dan konseling karier di SMK Syuhada Banjarmasin, sangat mendukung untuk karier yang bermutu; (2) analisis SWOT sangat membantu dalam menyelenggarakan layanan bimbingan dan konseling karier yang bermutu; (3) strategi Guru Bimbingan dan Konseling berjalan efektif dan efisien. Saran ditujukan untuk guru bimbingan dan konseling agar dalam menyusun dan melaksanakan program berdasarkan analisis SWOT agar pelaksanaan bimbingan dan konseling karier menjadi bermutu dan sustainable.
\end{abstract}

Kata kunci: strategi; bimbingan dan konseling; karier; mutu

Perencanaan karier setiap individu merupakan salah satu hal yang sangat penting saat ini. Perencanaan karier ini dimaksudkan untuk mempersiapkan individu tersebut dalam mengoptimalkan potensi yang dimilikinya. Setiap individu berhak untuk menentukan arah perencanaan kariernya ke depan. Terlepas dari semua itu, individu harus memahami betul akan dunia karier yang akan digeluti nanti,

Cara mengutip: Jarkawi, J., Ridhani, A. R., \& Susanto, D. (2017). Strategi Bimbingan dan Konseling Karier Bermutu pada Sekolah Menengah Kejuruan Syuhada Banjarmasin. Jurnal Kajian Bimbingan dan Konseling, 2(3), 123-131. http:// dx.doi.org/10.17977/um001v2i32017p123 
terlebih individu harus memahami potensi yang dimilikinya. Apakah potensi tersebut sudah sesuai dengan minat dan bakatnya, sehingga individu dapat menentukan dan merencanakan karier dengan tepat.

Peserta didik punya harapan agar memiliki karier yang bermutu, termasuk peserta didik SMK, karena kehidupan masa depan merupakan era globalisasi yang penuh dengan persaingan ketat dan menantang serta akan menjadikan kehidupan penuh dengan persaingan (Suharsaputra, 2015). Untuk mencapai karier yang bermutu perlu suatu strategi yaitu rancangan karier masa depan yang secara tepat dan akurat sebagai target capaian karier yang diharapkan. Mereka yang mampu mewujudkan targetnya adalah orang yang menggunakan strategi (Dess \& Miller, 1993).

Kehidupan yang sehat, bahagia dan sukses bergantung pada dua belahan otak (Pink, 2007). Untuk merancang karier masa depan yang bermutu secara akurat, tentunya peserta didik harus belajar dan berpikir secara rasional dengan memberdayakan kedua belahan otak. Otak kiri berpikir secara berurutan, logis, dan analisis; sedangkan otak kanan berpikirnya non-linear, intuitif, dan holistik.

Pelaksanaan program bimbingan dan konseling memberikan berbagai informasi melalui proses pembelajaran untuk memberdayakan otak agar berpikir rasional, dimana ketika peserta didik berpikir maka otak kiri dan otak kanan saling berkaitan karena otak kanan dan otak kiri bekerja beriringan (Levy dalam Hergenhahn \& Olson, 2014). Untuk mendapatkan suatu pekerjaan/profesi yang dicitacitakan, Peserta didik perlu berperan aktif dalam proses pendidikan melalui kegiatan pelaksanaan program layanan bimbingan dan konseling agar dapat menunjang karier yang bermutu dalam suatu pekerjaan/profesi yang dicita-citakan.

Karier merupakan pekerjaan dan profesi (Homby dalam Walgito, 2010), atau suatu rentangan aktivitas pekerjaan yang saling berhubungan (Murray dalam Supriatna \& Budiman, 2009). Peserta didik merencanakan karier untuk kehidupannya dengan melibatkan berbagai perilaku, kemampuan, sikap, kebutuhan, aspirasi, dan cita-cita sebagai satu rentang kehidupannya sendiri pada setiap kegiatan pelaksanaan program bimbingan dan konseling karier. Dalam memilih karier, peserta didik dipengaruhi dua faktor. Faktor tersebut adalah faktor internal dan eksternal (Winkel \& Hastuti, 2004). Faktor internal meliputi nilai kehidupan, taraf intelegensi, bakat khusus, minat, sifat-sifat, pengetahuan, dan keadaan jasmani. Faktor eksternal meliputi kemampuan orang tua atau keluarga dari segi ekonomi, promosi dari perguruan tinggi, dan dunia kerja. Dalam memilih karier perlu pemahaman yang jelas tentang diri, pengetahuan syarat diberbagai macam jalur pekerjaan dan penalaran yang benar tentang hubungan antara kedua kelompok fakta tersebut (Parson dalam Nathan \& Hill, 2012).

Dalam mempersiapkan perencanaan karier yang bermutu bagi peserta didik, diperlukan strategi layanan bimbingan dan konseling karier yang berorientasikan rasionalitas dengan pendekatan analisis SWOT. SWOT merupakan alat analisis yang ampuh untuk mengevaluasi dan merumuskan strategi dengan memaksimalkan kekuatan dan peluang, meminimalisir kelemahan dan menekan ancaman (Siagian, 1995). Analisis SWOT pada program layanan bimbingan dan konseling karier akan sangat membantu keefektifan dan efisiensi kegiatan.

Bimbingan karier merupakan suatu aktivitas yang dilakukan guru bimbingan dan konseling dengan tujuan menstimulasi dan memfasilitasi perkembangan karier seseorang sepanjang kehidupan (Mitchell \& Gibson, 2011). Hasil penelitian bidang bimbingan dan konseling karier menunjukkan bahwa kualitas layanan bimbingan dan konseling yang baik, harus mampu memberikan rasa kepercayaan diri, peningkatan prestasi belajar, serta ketepatan dalam memilih karier yang dikehendaki oleh peserta didik melalui informasi, karier baik secara individual maupun kelompok. Minat jurusan, kualitas layanan informasi dan pemahaman karier berkontribusi positif terhadap kemampuan dalam strategi mengambil keputusan karier (Lestari \& Supriyo, 2016), terdapat pula hubungan positif antara kepercayaan diri dan prestasi belajar dengan perencanaan karier (Komara, 2016).

Dalam mencapai karier bermutu perlu suatu strategi layanan bimbingan dan konseling, untuk itu diperlukan suatu penelitian dengan fokus bagaimana pelaksanaan bimbingan dan konseling karier pada SMK Syuhada Banjarmasin, Bagaimana pengaruh analisis SWOT terhadap pelaksanaan layanan 
bimbingan dan konseling karier pada SMK Syuhada Banjarmasin, dan strategi apa yang dilakukan guru bimbingan dan konseling pada SMK Syuhada Banjarmasin dalam membantu peserta didik memilih karier bermutu. Melalui metode studi kasus, tulisan ini akan mendeskripsikan pelaksanaan bimbingan dan konseling karier, Analisis SWOT yang dilakukan dan strategi yang dilakukan guru bimbingan dan konseling di SMK Syuhada Banjarmasin, sehingga terlihat strategi layanan bimbingan dan konseling mencapai karier yang bermutu oleh Guru Bimbingan dan Konseling di SMK Syuhada Banjarmasin.

\section{METODE}

Penelitian kualitatif ini dilakukan dengan melakukan penggalian data secara mendalam (Sugiono, 2005) terhadap program layanan bimbingan dan konseling. Metode yang digunakan adalah studi kasus dengan pendekatan etnografi yakni prosedur penelitian jenis kualitatif untuk mendeskripsikan dan menganalisis serta menginterprestasikan suatu perilaku dalam sebuah program melalui observasi dan wawancara (Creswell, 2015). Peneliti mengeksplorasi secara mendalam strategi program layanan bimbingan dan konseling melalui perilaku dua orang Guru Bimbingan dan Konseling, 32 orang peserta didik, satu orang Kepala Sekolah dan satu orang Wakil Kepala Sekolah sebagai partisipan, maka total partisipan adalah 36 orang

Teknik pengumpulan data dilakukan dengan observasi dan wawancara serta lewat data pendukung berupa dokumentasi tentang program pelayanan bimbingan dan konseling yang dilakukan berdasarkan analisis SWOT, kemudian strategi rancangan program bimbingan dan konseling berdasarkan hasil SWOT.

Analisis data dilakukan dengan mereduksi data yang didapat melalui penggalian data hasil observasi, wawancara dan didukung dengan data dokumentasi, kemudian dilakukan display data yang terkumpul baik tentang pelaksanaan bimbingan dan konseling karier, SWOT dan strategi program bimbingan dan konseling karier bermutu serta dilakukan verifikasi data secara triangulasi dan mengecek data antara peserta didik, Guru Bimbingan dan Konseling serta Kepala Sekolah dan Wakil Kepala Sekolah agar data yang diperoleh benar-benar valid dan reliabel. Selanjutnya di tarik suatu kesimpulan berupa deskripsi tentang: pelaksanaan bimbingan dan konseling karier di SMK Syuhada Banjarmasin; analisis SWOT pelaksanaan program bimbingan dan konseling karier yang bermutu; dan strategi Guru Bimbingan dan Konseling dalam menyelenggarakan layanan bimbingan dan konseling karier bermutu di SMK Syuhada Banjarmasin.

\section{HASIL}

\section{Pelaksanaan Bimbingan dan Konseling}

Dalam pelaksanaan layanan bimbingan dan konseling karier, guru bimbingan dan konseling 1 melaksanakan layanan konseling individual, sedangkan guru bimbingan dan konseling 2 melaksanakan konseling kelompok dengan teknik diskusi di ruang perpustakaan. Layanan konseling individual selama satu semester diberikan kepada 30 orang yang dibuktikan dengan bukti dokumentasi (buku kasus peserta didik). Layanan kelompok dilaksanakan empat kali, rata-rata 1 kelompok terdiri dari enam sampai tujuh orang dengan permasalahan tentang narkoba, membolos, sumbangan pembinaan pendidikan (SPP), dan 1 kali layanan tentang karier studi lanjut. Dari hasil pelaksanaan layanan tersebut, sebagian besar minat peserta didik lebih mengarah untuk bekerja dibandingkan melanjutkan studi. Sebagian kecil peserta didik ingin melanjutkan studi ke Politeknik Negeri Banjarmasin, Politeknik Hasnur, dan Universitas Islam Kalimantan Banjarmasin.

Salah satu bentuk layanan informasi yang diterima peserta didik adalah melalui brosur, selain itu Guru Bimbingan dan Konseling juga memberikan layanan untuk perencanaan karier peserta didik lewat konseling individu dan konseling kelompok. Peserta didik juga terkadang datang ke ruang bimbingan dan konseling untuk meminta informasi terkait karier. Setelah diskusi tentang karier, peserta didik merasa ada kepercayaan diri tentang kariernya. Hasil yang dipaparkan menunjukkan 
bahwa faktor yang memengaruhi pilihan masa depan karier berasal dari faktor internal maupun eksternal akan membentuk keunikan kepribadian. Masalah yang berkaitan dengan karier yang sering terjadi adalah kecenderungan putus sekolah karena peserta didik bekerja. Permasalahan semacam ini sering diatasi dengan layanan home visit yang diikuti pembebasan SPP.

\section{Pelaksanaan SWOT}

Analisis SWOT merupakan alat analisis yang ampuh untuk merumuskan strategi dengan memaksimalkan kekuatan dan peluang, meminimalisir kelemahan dan menekan ancaman yang harus dihadapi dan hasilnya dituangkan ke dalam program bimbingan dan konseling sehingga bimbingan dan konseling karier menjadi bermutu, seperti digambarkan pada gambar 1.

Dalam menyusun program bimbingan dan konseling bermutu, SMK Syuhada Banjarmasin secara internal telah melakukan needs assessment, tes IQ dalam rangka mengetahui potensi peserta didik untuk diberdayakan dalam merencanakan karier bermutu, menyiapkan sarana prasarana bimbingan dan konseling walaupun satu ruangan dengan ruang organisasi siswa intra sekolah (OSIS), Guru Bimbingan dan Konseling dengan latar belakang pendidikan S-1 jurusan bimbingan dan konseling, serta dukungan struktural berupa kebijakan pemberian waktu jam masuk kelas untuk memberikan layanan bimbingan dan konseling. Secara eksternal, SMK Syuhada Banjarmasin juga telah membangun kemitraan dengan beberapa perguruan tinggi tentang studi lanjut dan latihan kerja dengan Balai Latihan Kerja di Banjarbaru. Penggunakan telepon genggam sebagai sarana informasi dan teknologi yang juga diberdayakan untuk berkomunikasi dengan peserta didik guna mendukung pelayanan bimbingan dan konseling karier. Analisis internal dan eksternal ditindak lanjuti sampai melahirkan program bimbingan dan konseling karier bermutu yang pada akhirnya menciptakan suatu perencanaan karier peserta didik yang bermutu.

\section{Strategi yang Dilakukan}

Pada awalnya layanan bimbingan dan konseling di SMK Syuhada Banjarmasin tidak mendapatkan jam masuk kelas, hingga pada semester ganjil 2015/2016, Kepala Sekolah dan Wakil Kepala Sekolah bidang kurikulum membuat kebijakan baru yang memungkinkan Guru Bimbingan dan Konseling masuk kelas. Pada kelas sepuluh yang terdiri dari enam kelas, kedua Guru Bimbingan dan Konseling berbagi kelas, sehingga tiap Guru Bimbingan dan Konseling bertugas untuk tiga kelas. Pada pelaksanaan jam bimbingan dan konseling, Guru Bimbingan dan Konseling 1 memberikan layanan responsif, sedangkan layanan informasi dan orientasi diberikan Guru Bimbingan dan Konseling 2.

Berkaitan dengan layanan perencanaan karier dari masing masing Guru Bimbingan dan Konseling, Guru Bimbingan dan Konseling 1 menyebutkan bahwa peserta didik yang berminat melanjutkan studi di perguruan tinggi hanya sedikit, hal ini dikarenakan masalah ekonomi. Orang tua peserta didik

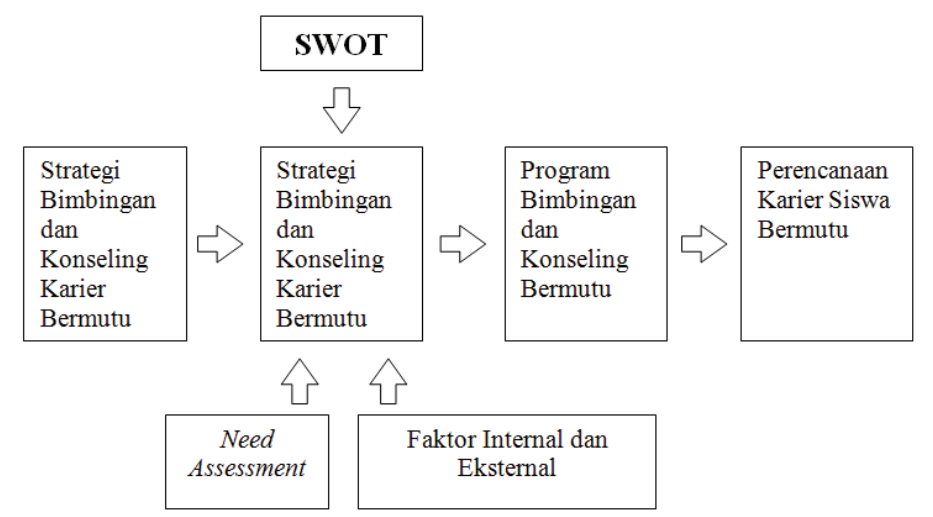

Gambar 1 Strategi Bimbingan dan Konseling Karier Bermutu 
yang rata-rata berprofesi sebagai petani dan buruh merupakan salah satu penyebabnya. Beberapa peserta didik juga mengaku bahwa mereka bekerja sambil bersekolah. Kedua Guru Bimbingan dan Konseling menyebutkan bahwa lapangan kerja peserta didik kebanyakan adalah bengkel. Terkait dengan hal ini, guru Bimbingan dan Konseling mengarahkan mereka untuk belajar di lembaga latihan kerja dan balai latihan kerja di Banjar Baru. Untuk layanan potensi diri, kedua Guru Bimbingan dan Konseling mengungkapkan bahwa mereka telah melakukan tes $I Q$ menggunakan alat tes milik teman sejawat.

Agar pelaksanaan layanan bimbingan dan konseling berjalan efektif dan efisien, Guru Bimbingan dan Konseling di SMK Syuhada Banjarmasin menerapkan strategi: (1) membuat rencana pemberian layanan (RPL) untuk layanan bimbingan dan konseling pribadi dengan tema memahami kemampuan diri, potensi keluarga, dunia kerja dan studi lanjut; (2) menelusuri minat dan bakat peserta didik dengan membagikan angket; (3) memberikan layanan bimbingan dan konseling pribadi dengan tema memahami kemampuan diri; (4) melakukan evaluasi hasil pelayanan bimbingan dan konseling pribadi dengan tema memahami kemampuan diri; (5) penjajakan tingkat kemampuan peserta didik dalam merencanakan karier dan studi lanjut peserta didik.

\section{PEMBAHASAN}

\section{Pelaksanaan Bimbingan dan Konseling Karier}

Pelaksanaan bimbingan dan konseling karier oleh Guru Bimbingan dan Konseling merupakan suatu layanan yang diberikan dalam mencapai karier bermutu dengan memberdayakan otak untuk belajar dan berpikir dalam merencanakan karier masa depan yang bermutu sehingga kehidupan menjadi sehat, bahagia dan sukses.

Pelaksanaan bimbingan dan konseling karier melalui home visit dikerjakan bersama dengan orang tua, wali kelas, kepala sekolah dan peserta didik agar dapat memberikan kontribusi terhadap keaktifan peserta didik untuk melanjutkan studi. Kerja sama tersebut ditindaklanjuti dukungan kepala sekolah lewat kebijakan pembebasan SPP. Kepala sekolah yang merupakan manajer dapat memengaruhi guru untuk mewujudkan tujuan yang diinginkan (Purwanti, 2013). Sebagai manajer, kepala sekolah harus mau dan mampu mendayagunakan seluruh sumber daya sekolah dalam meningkatkan visi, misi dan mencapai tujuan sekolah. Kepala sekolah berperan sebagai pemimpin dengan memberikan petunjuk dan pengawasan, meningkatkan kemauan tenaga kependidikan, dan membuka komunikasi dua arah (Rusmawati, 2013). Kebijakan kepala sekolah tentang bimbingan dan konseling merupakan suatu petunjuk dan alat komunikasi organisasi yang akan berdampak pada pelayanan bimbingan dan konseling. Bimbingan dan konseling karier yang dilaksanakan melalui konseling individual dan konseling kelompok (Hanggara, 2016; Muwakhidah \& Pravesti, 2017), akan memberikan rasa percaya diri bagi peserta didik tentang kariernya sebagai suatu pencerahan (Fiorentika, Santoso, \& Simon, 2016; Imro'atun, 2017; Marjanti, 2015)

Dalam pelaksanaan penyususunan program bimbingan dan konseling bermutu, guru bimbingan dan konseling melaksanakan analisis faktor internal (potensi intelegensi) dan faktor eksternal (pengetahuan tentang syarat di berbagai macam jalur pekerjaan dan studi lanjut) sebagai masukan dalam menyusun strategi layanan bimbingan dan konseling karier bermutu bagi peserta didik untuk merencanakan kariernya. Salah satu layanan yang dilaksanakan oleh Guru Bimbingan dan Konseling SMK Syuhada Banjarmasin adalah layanan informasi karier agar peserta didik dapat merencanakan karier untuk masa depannya dengan baik. Pemahaman yang diperoleh melalui layanan informasi digunakan sebagai bahan acuan dalam meningkatkan kegiatan dan prestasi belajar, mengembangkan cita-cita, menyelenggarakan kehidupan sehari-hari dan mengambil suatu keputusan (Hidayati, 2015). Program bimbingan karier terbukti efektif untuk meningkatkan kematangan karier peserta didik sehingga layak untuk diterapkan (Juwitaningrum, 2013) 


\section{Pelaksanaan SWOT}

Dari hasil analisis SWOT yang dilakukan Guru Bimbingan dan Konseling, terlihat bahwa proses pelaksanaan layanan bimbingan dan konseling karier yang bermutu bagi peserta didik telah dilakukan. Layanan tersebut juga disisipi pemberian bantuan perencanaan individual. Perencanan individual merupakan bantuan kepada peserta didik agar mampu merumuskan dan melakukan aktivitas berkaitan dengan perencanaan masa depan berdasarkan pemahaman akan kelebihan dan kekurangan diri, serta pemahaman akan peluang dan kesempatan yang tersedia (Rahman, 2008).

Guru bimbingan dan konseling melakukan suatu strategi bimbingan dan konseling karier bermutu dengan melakukan needs assessment kepada peserta didik untuk digunakan sebagai perencanaan program bimbingan dan konseling karier; menyusun visi dan misi; tujuan; sampai kemudian melahirkan program bimbingan dan konseling karier bermutu. Needs assessment memiliki peran yang penting dalam membuat perencanaan program bimbingan dan konseling karier. Data needs assessment murid dalam rangka penyusunan program bimbingan sekaligus dapat digunakan sebagai instrumen evaluasi program yang dilaksanakan pada akhir tahun pelayanan sehingga dapat menghasilkan deskripsi butir-butir kebutuhan perkembangan murid yang teridentifikasi dan sangat intens untuk direkomendasikan sebagai muatan kurikulum bimbingan klasikal (Barus, 2011). Needs assessment juga sangat mendukung untuk suatu perencanaan yang bermutu (Budiyanti \& Damayanti, 2015).

\section{Strategi yang Dilakukan}

Kebijakan Kepala Sekolah sangat signifikan dalam pelayanan bimbingan dan konseling agar setiap peserta didik mampu untuk merencanakan masa depan karier yang bermutu, termasuk peserta didik SMK. Kepala Sekolah yang berperan sebagai motivator, memberikan motivasi kepada guru dan pegawai, serta mengatur lingkungan fisik dan suasana kerja (Purwanti, 2013). Apabila guru dan pegawai memiliki motivasi yang positif maka guru dan pegawai akan lebih memerhatikan minat, perhatian dan ikut serta dalam suatu tugas dan pekerjaan. Guru dan pegawai akan melaksanakan pekerjaannya dengan baik apabila ada motivasi dorongan yang tinggi dari Kepala Sekolah.

Strategi pelaksanaan program bimbingan dan konseling karier bermutu yang dilakukan Guru Bimbingan dan Konseling menjadi efektif dan efisien karena melakukan pengembangan program bimbingan dan konseling yang desain pelaksanaannya tergambar dalam RPL bimbingan dan konseling yakni menetapkan materi layanan tentang memahami kemampuan diri, potensi keluarga, dunia kerja dan studi lanjut, serta melakukan evaluasi hasil pelayanan bimbingan dan konseling pribadi, sehingga memberikan makna bagi peserta didik tentang karier masa depannya. Sebagaimana telah ditegaskan dalam rekomendasi hasil penelitian Jarkawi, (2015) bahwa Guru Bimbingan dan Konseling mengembangkan program bimbingan dan konseling dengan merencanakan secara efektif dan efisien serta produktif dan outcome sehingga layanan yang diberikan memberikan makna kehidupan dan bermartabat bagi peserta didik sebagai customer primary. Agar lebih matang, perencanaan karier peserta didik dalam pemilihan karier perlu diawali dengan langkah persiapan dengan merumuskan dan menetapkan: tujuan karier; mengidentifikasikan sasaran (peserta didik) bimbingan karier; materi dan metode bimbingan karier; jadwal dan waktu pelaksanaan, dan menyiapkan ukuran keberhasilan layanan karier (Fitria, 2016).

Strategi program bimbingan dan konseling karier yang dilaksanakan dalam membantu mengatasi permasalahan peserta didik seperti: merokok, menggunakan narkoba, memiliki kecenderungan berhenti sekolah, dan belum memiliki perencanaan karier adalah dengan melakukan home visit.

Strategi pencapaian tujuan pelaksanaan layanan bimbingan dan konseling karier untuk masa depan karier peserta dianalisis dengan pendekatan SWOT, yakni: memaksimalkan kekuatan dan peluang, meminimalisir kelemahan dan menekan ancaman. Dari hasil analisis SWOT tersebut maka strategi pencapaian tujuan pelaksanaan layanan bimbingan dan konseling karier lebih fokus ke studi 
lanjut dan dunia kerja sesuai dengan minat dan bakat peserta didik serta latar belakang pendidikan sekarang ini. Dunia kerja lebih diminati karena kebanyakan keadaan ekonomi peserta didik lemah, sedangkan bagi peserta didik yang ekonominya tergolong mampu, berminat melanjutkan studi lanjut ke perguruan tinggi.

Strategi yang digunakan untuk menindak lanjuti hasil evaluasi program bimbingan dan konseling karier seperti: peserta didik merespon lebih banyak masalah dunia kerja dan tidak ada jam untuk melaksanakan layanan bimbingan dan konseling karier secara klasikal adalah dengan menetapkan kebijakan masuk kelas. Kebijakan ini merupakan salah satu faktor pendukung terlaksananya bimbingan dan konseling karier. Pemberian layanan bimbingan dan konseling menggunakan aplikasi Blackberry Messenger juga cukup mendukung pelaksanaan layanan bimbingan dan konseling karier dalam memantau perkembangan peserta didik. Teknologi informasi dalam bimbingan dan konseling memang memiliki kontribusi yang sangat besar bagi terlaksananya layanan bimbingan dan konseling (Setiawan, 2016).

Strategi dalam menghadapi hambatan seperti: belum adanya ruang khusus bimbingan dan konseling, terbatasnya alat psikotes, terbatasnya pengenalan potensi peserta didik, kurang optimalnya pelaksanaan konseling individual dan kelompok, waktu yang terbatas, pendanaan tidak ada, adalah dengan: memberdayakan unsur penunjang pelaksanaan bimbingan dan konseling karier berdasarkan analisis SWOT dari potensi internal berupa pemberdayaan ruang OSIS, alat psikotes teman sejawat, melaksanakan needs assessment melalui penyebaran angket, memberdayakan waktu yang disediakan semaksimal mungkin dengan menjadwalkan kegiatan pelaksanaan bimbingan dan konseling karier serta menyusun program bimbingan dan konseling karier dan RPL.

\section{SIMPULAN}

Analisis SWOT terhadap layanan bimbingan dan konseling dengan melihat dari faktor internal dan eksternal sangat strategis membantu dalam melihat kekuatan, dan kelemahan program layanan bimbingan dan konseling karier bermutu oleh Guru Bimbingan dan Konseling di SMK Syuhada Banjarmasin. Pelaksanaan analisis juga dapat dijadikan acuan dalam menganalisis kebutuhan peserta didik sesuai dengan apa yang dibutuhkan oleh peserta didik dalam merencanakan karier yang bermutu. Strategi Guru Bimbingan dan Konseling di SMK Syuhada Banjarmasin dalam pelaksanaan layanan bimbingan dan konseling adalah dengan menentukan waktu layanan, materi layanan, metode dan strategi layanan serta evaluasi dan tindak lanjut. Keadaan ini membuat layanan bimbingan dan konseling berjalan efektif dan efisien serta bermutu.

Saran disampaikan kepada Guru Bimbingan dan Konseling agar melakukan analisis SWOT dan menentukan strategi bimbingan dan konseling agar dampak kebermaknaan layanan benar-benar dirasakan oleh stakeholder sekolah, terlebih peserta didik yang dilayani.

\section{DAFTAR RUJUKAN}

Barus, G. (2011). Pengembangan Instrumen Asesmen Kebutuhan Perkembangan untuk Penyusunan Kurikulum dan Evaluasi Program BK. Jurnal Penelitian dan Evaluasi Pendidikan, 15(1), 2246.

Budiyanti, H., \& Damayanti, N. A. (2015). Penilaian Kebutuhan Pelatihan pada Tingkat Individu Petugas Rekam Medis. Jurnal Administrasi Kesehatan Indonesia, 3(1), 70-79.

Creswell, J. (2015). Riset Pendidikan: Perencanaan, Pelaksanaan, dan Evaluasi Riset Kualitatif \& Kuantitatif. Yogyakarta: Pustaka Pelajar.

Dess, G. G., \& Miller, A. (1993). Strategic Management. McGraw-Hill.

Fiorentika, K. F., Santoso, D. B., \& Simon, I. M. (2016). Keefektifan Teknik Self-instruction untuk Meningkatkan Kepercayaan Diri Siswa SMP. Jurnal Kajian Bimbingan dan Konseling, 1(3), 104-111. http://dx.doi.org/10.17977/um001v1i32016p104 
Fitria, K. N. (2016). Layanan Bimbingan Karir dalam Meningkatkan Perencanaan Karir Siswa di $S M K / S M F$ Indonesia. Universitas Islam Negeri Sunan Kalijaga.

Hanggara, G. S. (2016). Keefektifan " Proses Guru " Sebagai Teknik Bimbingan Kelompok untuk Meningkatkan Kemampuan. Jurnal Kajian Bimbingan dan Konseling, 1(4), 148-157. http:// dx.doi.org/10.17977/um001v1i42016p148

Hergenhahn, B. R., \& Olson, M. H. (2014). Theories of Learning (Teori Belajar). Jakarta: Kencana Prenadamedia group.

Hidayati, R. (2015). Layanan Informasi Karir Membantu Peserta Didik dalam Meningkatkan Pemahaman Karir. Jurnal Konseling Gusjigang, 1(1). http://dx.doi.org/10.24176/jkg.v1i1.258

Imro'atun, S. (2017). Keefektifan Layanan Konseling Kelompok untuk Meningkatkan Kepercayaan Diri Siswa Sekolah Menengah Pertama. Jurnal Kajian Bimbingan dan Konseling, 2(2), 50-57. http://dx.doi.org/10.17977/um001v2i22017p050

Jarkawi, J. (2015). Perencanaan Program Bimbingan dan Konseling di SMP 25 Banjarmasin. Jurnal Konseling Gusjigang, 1(1). http://dx.doi.org/10.24176/jkg.v1i1.290

Juwitaningrum, I. (2013). Program Bimbingan Karir untuk Meningkatkan Kematangan Karir Siswa SMK. PSIKOPEDAGOGIA Jurnal Bimbingan dan Konseling, 2(2), 132-147. http://dx.doi. org/10.12928/psikopedagogia.v2i2.2580

Komara, I. B. (2016). Hubungan antara Kepercayaan Diri dengan Prestasi Belajar dan Perencanaan Karir Siswa SMP. PSIKOPEDAGOGIA Jurnal Bimbingan dan Konseling, 5(1), 33. http:// dx.doi.org/10.12928/psikopedagogia.v5i1.4474

Lestari, D., \& Supriyo, S. (2016). Kontribusi Minat Jurusan, Kualitas Layanan Informasi Karir, dan Pemahaman Karir terhadap Kemampuan Mengambil Keputusan Karir. Jurnal Bimbingan Konseling, 5(1), 47-54.

Marjanti, S. (2015). Upaya Meningkatkan Rasa Percaya Diri Melalui Konseling Kelompok Bagi Siswa XII IPS 6 SMA 2 Bae Kudus Tahun Pelajaran 2014/2015. Jurnal Konseling Gusjigang, 1(2). http://dx.doi.org/10.24176/jkg.v1i2.412

Mitchell, M. H., \& Gibson, R. L. (2011). Bimbingan dan Konseling. Yogyakarta: Pustaka Pelajar.

Muwakhidah, M., \& Pravesti, C. A. (2017). Keefektifan Konseling Kelompok Cognitive Behavior Therapy untuk Mengurangi Keraguan Pengambilan Keputusan Karier Siswa Sekolah Menengah Kejuruan. Jurnal Kajian Bimbingan dan Konseling, 2(2), 66-75. http://dx.doi.org/10.17977/ um001v2i22017p066

Nathan, R., \& Hill, L. (2012). Konseling Karier. Yogyakarta: Pustaka Pelajar.

Pink, D. H. (2007). Misteri Otak Kanan Manusia: Keajaiban Otak Kanan Kita?, Mengapa Para Pengguna Otak Kanan Dapat Menguasai Dunia?, Bagaimana Rahasia Menciptakan Pikiran yang Benar-benar Baru dan Fresh? Think.

Purwanti, S. (2013). Peran Kepemimpinan Kepala Sekolah dalam Meningkatkan Disiplin Kerja Guru dan Pegawai di SMA Bakti Sejahtera Kecamatan Kongbeng Kabupaten Kutai Timur. eJournal Administrasi Negara, 1, 210-224.

Rahman, F. (2008). Penyusunan Program BK di Sekolah. Yogyakarta: Universitas Negeri Yogyakarta.

Rusmawati, V. (2013). Peran Kepemimpinan Kepala Sekolah Dalam Upaya Meningkatkan Disiplin Kerja Guru Pada SDN 018 Balikpapan. e-Journal Administrasi Negara. 1 (2), 395-409.

Setiawan, M. A. (2016). Peranan Teknologi Informasi dalam Bimbingan dan Konseling. Bitnet Jurnal Pendidikan Teknologi Informasi, 1(1), 46-49.

Siagian, S. P. (1995). Manajemen Stratejik. Jakarta: Bumi Aksara.

Sugiono, P. (2005). Cara Mudah Menyusun: Skripsi, Tesis, dan Disertasi. Bandung: ALFABETA.

Suharsaputra, U. (2015). Manajemen Pendidikan Perguruan Tinggi. Bandung, Indonesia: PT Refika Aditama. 
Supriatna, M., \& Budiman, N. (2009). Bimbingan Karier di SMK.

Walgito, B. (2010). Bimbingan + Konseling (Studi \& Karier). Yogyakarta: CV Andi Offset.

Winkel, W. S., \& Hastuti, S. (2004). Bimbingan Karir di Institusi Pendidikan. Jakarta: Media Abadi. 